\title{
Congenital nephrotic syndrome with acute renal failure: questions
}

\author{
Elena Tudorache • Julien Hogan • Marie-Emilie Dourthe • Béatrice Quinet • \\ Emmanuel Grimprel • Anne-Laure Sellier-Leclerc • Tim Ulinski
}

Received: 27 January 2011 /Revised: 21 February 2011 / Accepted: 24 February 2011 /Published online: 24 May 2011

(C) IPNA 2011

Keywords Congenital syphilis $\cdot$ Congenital nephrotic syndrome $\cdot$ Renal failure $\cdot$ Syphilis $\cdot$ Treponema pallidum serology $\cdot$ Maternal-foetal infection

\section{Case presentation}

We report a case of congenital nephrotic syndrome with acute renal failure associated with multiple organ injury requiring peritoneal dialysis. Maternal serology, including hepatitis B, HIV, and Treponema pallidum hemagglutination (TPHA) and the Venereal Disease Research Laboratory (VDRL) tests were all negative at 10 weeks of gestational age (GA). At 34 weeks of gestation, the ultrasound examination showed hydrops fetalis. The umbilical cord puncture found anemia, with hemoglobin at $8.4 \mathrm{~g} / \mathrm{dl}$, thrombocytopenia at $43,000 / \mathrm{mm}^{3}$, cytomegalovirus (CMV)-polymerase chain reaction (PCR) and parvovirus-PCR were negative. The child was born at 35 weeks of gestational age and immediately transferred to an intensive care unit because of septic shock. The clinical findings were sclerema neonatorum with blisters, hepatomegaly, splenomegaly, and macroscopic hematuria. The

The answer to this question can be found at http://dx.doi.org/10.1007/ s00467-011-1845-6

E. Tudorache $\cdot$ J. Hogan $\cdot$ M.-E. Dourthe $\cdot$ B. Quinet $\cdot$

E. Grimprel · A.-L. Sellier-Leclerc $\cdot$ T. Ulinski $(\bowtie)$

Department of Pediatric Nephrology, Armand Trousseau

University Hospital and University Pierre and Marie Curie

(UPMC),

26 Avenue du Dr Arnold Netter,

75012 Paris, France

e-mail: tim.ulinski@trs.aphp.fr initial blood analysis showed hemoglobin $11 \mathrm{~g} / \mathrm{dl}$, thrombocytopenia $22,000 / \mathrm{mm}^{3}$ (despite intrauterine blood and platelets transfusion), reticulocytes $>150,000 / \mathrm{mm}^{3}$, C-reactive protein (CRP) $233 \mathrm{mg} / \mathrm{L}$, urea $4 \mathrm{mmol} / \mathrm{L}$, serum creatinine $72 \mu \mathrm{mol} / \mathrm{L}$, proteins $56 \mathrm{~g} / \mathrm{L}$, serum glutamic oxaloacetic transaminase (SGOT) $482 \mathrm{UI} / \mathrm{L}$, serum glutamic pyruvic transaminase (SGPT) $224 \mathrm{UI} / \mathrm{L}$, haptoglobin $<200 \mathrm{ng} / \mathrm{ml}$, total bilirubin $108 \mu \mathrm{mol} / \mathrm{L}$, and lactate dehydrogenase (LDH) $1,042 \mathrm{UI} / \mathrm{L}$. Treatment was immediately initiated by amoxicillin, cefotaxime, and gentamicin. All bacteriological findings were initially negative (blood culture, spinal puncture, peripheral samplings). At the 7th day of life, serum creatinine decreased to $39 \mu \mathrm{mol} / \mathrm{L}$.

Since birth, the patient had a macroscopic hematuria. The ultrasound found both kidneys increased in size, hyperechogenic, but without Doppler flow abnormality. A nephrotic syndrome was diagnosed at 4 days of life (proteinuria $60 \mathrm{~g} / \mathrm{L}$ and albuminemia $20 \mathrm{~g} / \mathrm{L}$ ). Hematuria was $10 \times 10^{6} / \mathrm{ml}$ and hemoglobinuria $>600 \mu \mathrm{g} / \mathrm{dl}$. Symptomatic treatment was initiated by albumin, anticoagulation, and recombinant erythropoietin. At the 9th day of life, CRP was $51 \mathrm{ng} / \mathrm{ml}$, and hemoculture showed Staphylococcus epidermidis, motivating vancomycin treatment. Serum creatinine increased concomitantly to $262 \mu \mathrm{mol} / \mathrm{L}$.

\section{Questions}

1. Which investigations should be performed (repeated) rapidly?

2. Which diagnosis is the most probable to explain the clinical presentation? 